\title{
de Grossi, María Inés Saravia. Sófocles. Una interpretación de sus tragedias. La Plata: Universidad Nacional de La Plata, 2007 (406 p.) ISBN: 9789503404096
}

O livro de María Inés Saravia de Grossi, professora da Universidade de La Plata, na Argentina, pertence a uma série de estudos que a pesquisadora vem fazendo nos últimos anos sobre as tragédias de Sófocles. Seu objetivo principal é analisá-las a partir

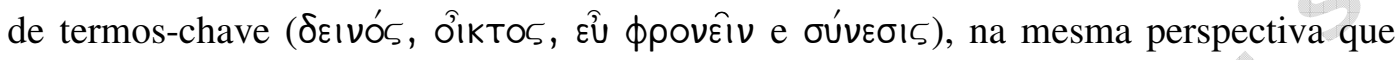
Schlesinger, pensador alemão da primeira metade do século $\mathrm{XX}$, empregou-os para estudar a Ética a Nicômano.

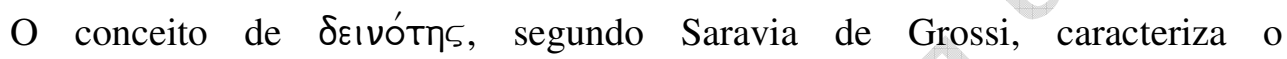
comportamento humano como "el impulso a la propia que alienta a la propia conduta. $\mathrm{O}$ conceito implica um estado de emoción violenta ante lo horrendo, lo maravilloso o bien lo enigmático. $\Delta \varepsilon ı$ vós, entonces, es precisamente lo que supera la capacidad del

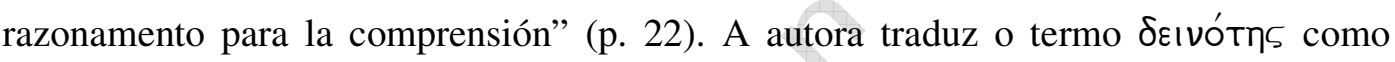
pasmoso, entendendo que assim demonstra melhor que as realizações dos homens são, ao mesmo tempo, maravilhosas e terríveis. Esta característica humana é tanto a fonte de sofrimentos (ôlkTOS) dos protagonistas quanto a origem da compaixão dos espectadores/ leitores. Esse sofrimento, por sua vez, é o caminho para a reflexão (عû

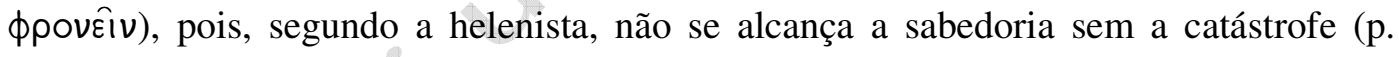

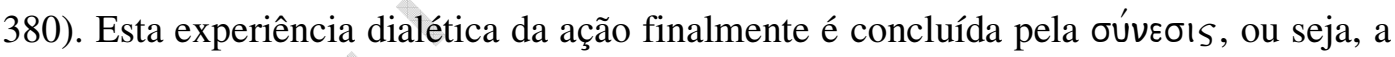
compreensão da "verdadeira condição do ser humano e do poder inescrutável da divindade" (p. 381), sendo a moderação dos sentimentos a principal lição do tragediógrafo.

A partir dessa perspectiva, cada tragédia é apresentada de forma esquemática. Primeiro, uma rápida exposição de teorias explicativas sobre elas, desde Jebb. Apoiada em análise filológica cuidadosa, Saravia Grossi examina cada trecho em que o conceito de $\delta \varepsilon ı$ ós aparece nas peças sofoclianas. Desta forma, ela não só constrói sua teoria explicativa e interpretativa da obra como também teoriza sobre todo o teatro de Sófocles. Além disso, em seu livro, a investigadora argentina busca identificar os

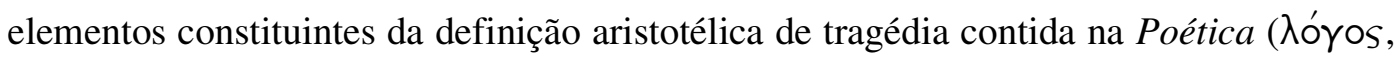

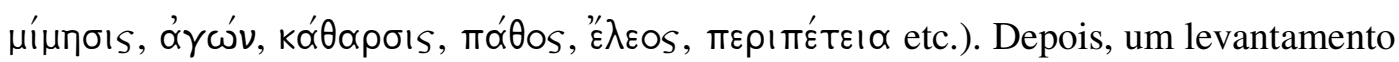
quantitativo de $\delta \varepsilon ı$ ós e sua família; e, por fim, para corroborar sua teoria, busca 
trechos nos quais os conceitos que apresentam solidariedade semântica com $\delta \varepsilon ı$ vós (ou

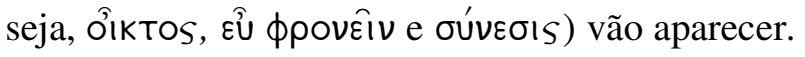

O livro de Grossi abunda em boas sugestões sobre as personagens de Sófocles. No entanto, fica claro que a autora, substituindo os termos-chave da definição de tragédia na Poética (1449b), faz uma justaposição da sua teoria com a de Aristóteles ao afirmar, como o filósofo, que ela é a representação de ações ( $\delta \varepsilon ı$ ๖í) que inspiram terror

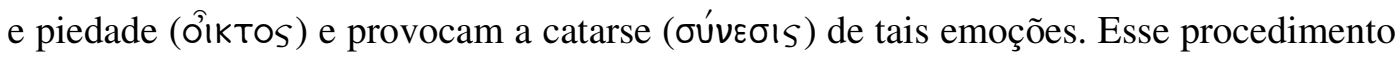
levou Grossi a adequar os textos à sua teoria para corroborar suas afirmações. Por exemplo, no capítulo em que analisa Electra, diz a autora: Electra "se descubre como una obra que inspira " $\iota^{\prime} \lambda \varepsilon \circ \varsigma^{\prime}$ " (p. 255); “el espectador ha escuchado el canto de tristeza de Electra en la Párodos y sabe que la hija de Agamenón comprende su situación, oúveoıs,

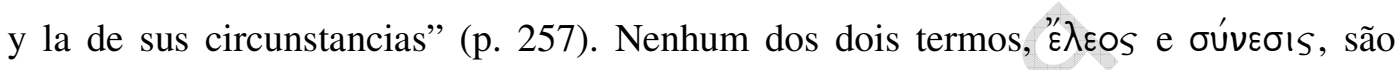
encontrados na peça em questão.

A própria tradução do termo-chave de sua análise é discutível. $\Delta \varepsilon ı$ ós apresenta inúmeros sentidos e uma riqueza semântica que "pasmoso" não abarca, empobrecendo a tradução poética. Isso fica evidente quando o vemos aplicado ao texto grego. Por exemplo, podemos realmente até empregar "pasmoso" no famoso coro de Antígona

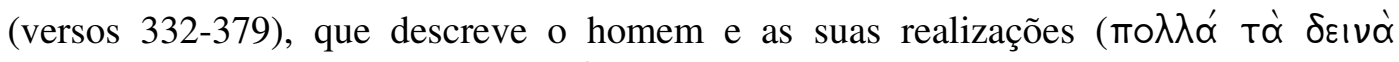

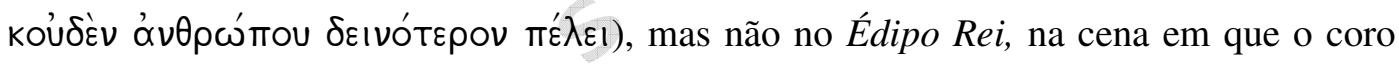
externa seus sentimentos ao ver Édipo saindo do palácio com os olhos vazados (verso

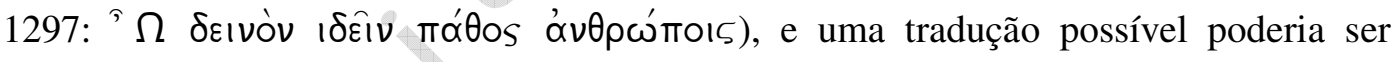
"terrível", "medonho" ou "funesto".

Uma abordagem mais unitarista, como a empreendida por Grossi, tem o mérito de evidenciar conexões entre as obras e o contexto histórico-cultural em que elas foram produzidas. Mas, ao mesmo tempo, perdem-se as especificidades, as particularidades de cada obra, que têm inesgotáveis perspectivas de abordagem. Ademais, não podemos perder de vista que temos para trabalhar, em termos da tragédia grega, somente uma pequena parte do realmente produzido, e que generalizações devem ser feitas com cautela.

José Gonçalves Poddis Programa de Pós-Graduação em Letras: Estudos Literários - FALE/UFMG jpoddis@hotmail.com 